mining blood to them with purgatives? In conclusion, I publicly, and simultaneously with hundreds of others who mentally ejaculate the same, render my best thanks to Guthrie for his well-timed and effectual championship, of which our present list of surgical fees (extended though it may be) is the proof.

Norwich, 1848.

\section{ASIATIC CHOLERA SUCCESSFULLY TREATED BY CHLOROFORM.}

By JAMES MOFFAT, M.D., North Berwick.

ThreE days ago a house-painter from Dunbar, about fifty years of age, being here on a visit, was seized, about eight in the morning, with the usual symptoms of cholera. He was totally neglected till two P.M., when I was sent for, but being from home, I did not see him till five P.M. In the meantime the symptoms had increased to a degree which caused the greatest alarm; and when I saw him, the extremities were cold, the body blue-not the slightest pulsation could be felt in either arm, and the vomiting, purging, and cramps, were absolutely fearful.

I gave him twenty five drops of laudanum, which were in stantly vomited up. I then gave him a dose of chloroform by inhalation. He fell gently back, the vomiting ceased, and he lay quite calm. In twelve or fifteen minutes he came out of the anzesthesia, and looked placidly around him, but in a few minutes more he began to feel the pains and cramps in his legs, and of his own accord actually cried out for mercy's sake to give him more of the chloroform, for he felt the pains coming back, at the same time eagerly catching hold of the chloroformed handkerchief, and applying it to his mouth. I put him over again. He lay quietly, and I kept up the anæsthesia, more or less, for four hours, during which time the body was kept warm by a load of bed-clothes, bottles of hot water, \&c. I gave, occasionally, a very little brandy, camphor, \&c.

When I saw him first, he was evidently on the eve of dissolution, from the extreme violence of the disease; but in the midst of the cramps, vomiting, and purging, I gave him chloroform, and from that moment every symptom ceased, and he is now quite recovered.

The case is of the highest importance, as showing the power of chloroform over cholera. Nothing could be more decisive. For the long period of nine hours there was incessant vomiting and purging, with pains and cramps, but the very instant the chloroform was administered they all disappeared, and never returned.

This is the first cholera patient I have had under my charge since I wrote on the subject in The LANCET for Nov. 11 and Nov. 18, 1848; and the rules there laid down were successfully pursued in the present case; and were the same plain course uniformly adopted, there is every reason to think that cholera would soon disappear from the land.

January 11, 1819 .

\section{REPORT OF A DEATH FROM RUPTURE OF THE ARCH OF THE AORTA.}

\section{By JOHN PARKIN, Esq.,}

HOUSE SURGEON TO THE WARRINGTON DISPENSARY,

ON the 12 th of November, about ten o'clock in the morning, a messenger arrived in great haste, wishing me to go immediately to see a man who had dropped down suddenly, and was reported to be dead. I immediately went, and, to my astonishment, found the individual to be an old man whom I had met in the street but ten minutes before. He was quite dead, but the surface of the body was warm, and there was an anæmiated, exsanguinous appearance of the countenance. This same man I had attended a week or two before, for pleuritic inflammation of the left side. He was then making no complaint elsewhere, except of an occasional pain in the back, between the shoulders, and I therefore did not suspect any mischief elsewhere.

On the 14th of November, assisted by Mr. Ollard, I made a post-mortem examination, by order of the coroner. $\mathrm{He}$ was sixty years of age, and appeared to be a tolerably strong, muscular man. His friends informed me that he had generally enjoyed good health, and had not complained much until my last attendance upon him. His occupation was that of a hawker.

The lungs were found to be tolerably healthy, excepting the posterior part of the middle lobe of the right lung, which had evidently suffered from inflammation, being firm and uncrepitating. A portion of the pleura costalis of the left side showed signs of recent inflammation, and there was an effusion of a quantity of serum; but the most remarkable appearance was a vast quantity of extravasated blood, amounting to about five pounds weight, occupying the left side of the chest, almost shutting out from view the left lung and pericardium. This at once gave a clue as to the cause of death. The heart was next examined, and on opening the pericardium, two ounces of serum escaped. There were no adhesions between the two, nor any signs of previous inflammation. The heart itself was quite healthy in every respect, but very pale and exsanguinous. The great vessels leading from the heart were next submitted to careful examination, and at the arch of the aorta, about an inch beyond where the left carotid and subclavian arteries are given off, was found a rupture, in appearance like a slit, about one-third of an inch in length. Immediately above this, was another rupture, but more circular than the former, and not so large. The artery was very much diseased, being so much degenerated, that it tore up into shreds, like so much old linen. The cause of death being so apparent in this case, and my time limited, we did not pro. secute the examination any further. The rupture of this artery would eminently account for the appearances observed, both internally and externally, and for the instantaneousness of his death.

Warrington, November, 1848.

\section{OBSERVATIONS ON THE DEVELOPMENT OF THE FAT VESICLE.}

BY ARTHUR HASSALL, M.D.

WHEN the difficulty of determining the exact structure of the fat vesicle is considered,-a difficulty arising from the extreme tenuity of its cell-wall, and the opacity of its contents, -it is scarcely surprising that we should yet be without any consistent account of the modes of development and growth of the fat vesicle.

This hiatus in the structural history of that peculiar animal tissue, fat, the present brief remarks are intended in some measure to fill up.

When the little fatty masses which are met with so abundantly in the neck, in the neighbourhood of the thyroid and thymus glands, as also in some other situations in a foetus nearly or quite arrived at maturity, are examined, it will be observed, by the use of a lens only, that these masses are each composed of a number of distinct and opaque bodies of various sizes, presenting a smooth outline, having a more or less rounded or oval form, and held loosely together by fibrocellular tissue, the extension of which forms the envelope which invests each of these bodies. It will also be further noticed, that each mass of fat is supplied with one or more bloodvessels, and that these break up into numerous lesser branches, one of which goes to each of the previouslydescribed bodies, being conveyed to it by the connecting fibrous tissue; and that, having reached this body, it undergoes a further subdivision, the branches extending over its entire surface.

In continuation of these observations, it will be remarked, that each of these peculiar bodies bears a close resemblance, in its general aspect, to a lobe of a sebaceous gland-a resemblance which, as will be seen almost immediately, extends even to its internal structure.

If a number of these bodies be torn into fragments with fine needles, and be examined with a half or quarter inch object glass, it will be observed that the cavities of some of them are filled with cells of a large size, and which again are occupied with numerous globules of various dimensions, presenting many of the characters of oil globules, but being of greater consistence. These cells, save by their somewhat larger size, it is impossible to distinguish from the perfect cells of sebaceous glands; so complete, indeed, is this resemblance, that at first sight I did not hesitate to regard them as belonging to some sebaceons gland, and which I was much astonished to encounter in such a situation. Others of these peculiar bodies, which may be termed "fat cysts," contain a mixture, in variable proportions, of these compound cells and of free globules, which, however, it is to be observed, are generally of larger size than those contained within the compound or parent cells. Lastly, others of these bodies enclose no compound cells, but are filled with globules of still larger size.

Now the curious part of this history is, that it is these 